Grasas y Aceites

Vol. 54. Fasc. 4 (2003), 339-342

\title{
Effect of sucrose polyesters on crystallization rate of vegetable ghee: solid fat content study
}

\author{
By Mohammad Ibrahim Nasir
}

Research Department, Jahan Vegetable Oil Co.No. 16, Daman Afshar St., Wali-Assr Ave. Above Wanak Sq., Tehran --19697, Iran.

\section{RESUMEN}

Efecto de los poliésteres de sacarosa sobre la velocidad de cristalización del ghee vegetal: estudio del contenido en grasa sólida.

Se ha investigado, mediante el contenido en grasa sólida (SFC) por resonancia magnética nuclear pulsada ( $p$-NMR), la velocidad de cristalización de mezcla de aceite de la soja y aceite de semilla del algodón parcialmente hidrogenada utilizada en la elaboración de ghee vegetal (vanaspati). Se han estudiado los efectos de añadir ésteres de sacarosa de ácidos grasos o poliésteres de sacarosa (SPE) sobre la velocidad de cristalización de la mezcla grasa. Se agregó tetraestearato de sacarosa DK ester F-10 (estearato $70 \%$-palmitato $30 \%$ ) a la grasa en diferentes concenraciones $(0.5 \%$ y $1.0 \%)$. Se determinaron las variaciones del SFC, a temperatura constante de $15^{\circ} \mathrm{C}$, durante 25 horas en muestras que contenían $0.5 \%$ y $1.0 \%$ de DK ester F-10 (DK F-10) y una muestra en blanco. Se determinaron los contenidos en grasa sólida a las $2,5,9,13$ y 25 horas. El incremento en SFC fue continuo en todas las muestras durante las 25 horas, presentando un brusco aumento durante las primeras dos horas. Las muesto un brusco a nín F-10, no mostraron ninguna diferencia significativa en SFC durante las primeras trece horas, mientras que la muestra con el $1.0 \%$ de DK F-10, mostró un SFC superior a las otras dos, durante todo el período de tiempo. EI SFC de la muestra con el $1.0 \%$ de DK F-10, a las 13 horas, es igual al de la muestra en blanco $(0.0 \%)$ a las 25 horas. El punto de fusión de las mismas muestras aumentó con la concentración en DK F-10. Los resultados del SFC demuestran que la adición de un $1.0 \%$ de DK F - 10 reduce el tiempo de cristalización del ghee vegetal mientras que un $0.5 \%$ no produce ningún efecto significativo.

PALABRAS-CLAVE: Contenido en grasa sólida - Ghee vegetal - Poliesteres de sacarosa -- Velocidad de cristalización.

\section{SUMMARY}

Effect of sucrose polyesters on crystallization rate of vegetable ghee: solid fat content study.

Crystallization rate of partial hydrogenated blend of soybean oil and cottonseed oil used for making vegetable ghee (vanaspati) was investigated, by solid fat content (SFC) using pulsed nuclear magnetic resonance ( $\mathrm{p}$-NMR). The effects of adding sucrose fatty acid esters or sucrose polyesters (SPE) on the crystallization rate of the blend fat were studied. Sucrose tetrastearate DK ester F-10 of the blend fat were fat at different concentration, namely $0.5 \%$ and $1.0 \%$. Blank sample and sample containing $0.5 \%$ and $1.0 \%$ DK ester F-10 / (DK F-10) were chosen

Present Address: Department of Chemical and Biochemical Engineering, Faculty of Engineering, University of Western Ontario, London, Ontario N6A 5B9, Canada. to measure the change in SFC at constant temperature of $15^{\circ} \mathrm{C}$ for a period of $25 \mathrm{hr}$. Five determinations of SFC were taken to the fat samples during the $25 \mathrm{hr}$ i.e. $2,5,9,13$ and $25^{\text {th }} \mathrm{hr}$. SFC vs. time of crystallization of the three samples showed continuous increasing in SFC in all samples during the $25 \mathrm{hr}$, with sharp increasing at the first two hours. Samples containing $0.0 \%$ and $0.5 \%$ DK F-10, showed no significant difference in SFC during the first thirteen hours, while sample containing 1.0\% DK F-10, showed higher SFC than the other two samples, through out the period. The amount of SFC for $1.0 \%$ DK F-10 sample at the 13 hour is equal to the SFC of the blank $(0.0 \%)$ sample at the $25^{\text {th }}$ hour. Melting point of the same samples increased with the increasing DK F-10 concentration in the fat samples. The results of SFC make it sure that the addition of $1.0 \%$ DK F- 10 will shorten the time required for the crystallization of vegetable ghee while the addition of $0.5 \%$ will not have significant effect.

KEY-WORDS: Crystallization rate -- Solid fat content - Sucrose Polyesters - Vegetable ghee.

\section{INTRODUCTION}

Vegetable ghee or Vanaspati was developed as an alternative to ghee (an hydrous butter fat). Vegetable ghee is an all vegetable oil -- based product (Ray \& Bhattacharyya, 1996). In Jahan Vegetable Oil Co., its formulation is based on partially hydrogenated blend of soybean -cottonseed oils (90-10\%), with a melting point of 32 $-40^{\circ} \mathrm{C}$. In its liquid state, it is filled into tin cans and allowed to crystallize very slowly under well controlled conditions (Gander, 1976; Nor Aini, 1993). Since tempering the fat in a constant temperature room are expensive and having logistical problems, some attempts have taken place to reduce the tempering time (O'Brein, 1996; DANISCO, 1998; Nasir, 2001). Sucrose fatty acid esters or sucrose polyesters (SPE) are well known as food emulsifiers and inhibiter of fat crystallization (Herrera \& Marquez Rocha, 1996; Nakamura, 1997; DKS, 1998). But there are very little reports indicated that the use of some SPE would increase the crystallization of fat and so to reduce the tempering time (Nasir, 2001; Yuki et al., 1990). Sucrose tetrastearate DK ester F-10 (DK F-10) was chosen for this task.

The solid fat content (SFC) is strongly dependent on crystallization and tempering, and so crystallization process can be monitored through 
SFC measurement (Breitschuh \& Windhab, 1996). Since SFC can be measured by pulsed nuclear magnetic resonance (p-NMR) without destroying or disturbing the crystal structure at a short time. Its simple and automized the measurement (Breitschuh \& Windhab, 1996; Herrera et al., 1996; Van Duynhoven et al., 1999). These conditions of measurement for SFC of the fat make it quite similar to the vegetable ghee processing line. In addition we can detect the change in the SFC, which mean the amount of crystals for many samples at the same time.

The aim of the present works was to evaluate the effects of DK F-10 on crystallization rate of partially hydrogenated blend oils used for producing vegetable ghee by measuring SFC of the fat and comparing the results with the other analyses methods of similar samples of fat, so that we can verify the new results with our previous work (Nasir, 2001).

\section{EXPERIMENTAL}

\subsection{Materials}

The hydrogenated blend soybean $(90 \%)$ cottonseed $(10 \%)$ oils are from Jahan Vegetable Oil Co. plant. SPE used are DK F-10 (70\% stearate -$30 \%$ palmitate) from Daiichi Kogyo Seiyaku Co. (Tokyo, Japan). DK F-10 used are of Hydrophilic -Lipophilic Balance (HLB) $=1$.

\subsection{Apparatus and Method}

Samples preparation follows the method described by DKS (DKS, 1998) and reported before (Nasir, 2001). The Official and Tentative Methods of the American Oil Chemists Society were followed for the determination of the characteristics of fat samples used in this work (AOCS, 1985) are shown in Table I. Fatty acid composition of fat was determined by transesterification with sodium methoxid and analysis of the methyl esters by gas chromatography using a Varian Star 3400 CX GC (Varian, Inc., Netherlands) equipped with flame ionization detector (FID) with a fused--silica Chrompack CP-Sil 88 ( $100 \mathrm{~m} \times 0.25 \mathrm{~mm}$ ID) capillary column was used in the analyses. Helium was the carrier gas. The oven temperature was maintained at $175^{\circ} \mathrm{C}$, the injector and detector temperature at $220^{\circ} \mathrm{C}$ and $230^{\circ} \mathrm{C}$, respectively. The composition of each peak was identified with those of standards run on the same column under similar conditions. Fatty acid composition was shown in Table I.

The SFC of the vegetable ghee samples was determined by $p$-NMR using the Bruker Minispec NMS 120 NMR Analyzer (Bruker, Rheinstetten, Germany). Each sample was run in duplicate and the values were averaged. Two samples from fat
Table I

Chemical properties of blend soybean-cottonseed oil

\begin{tabular}{lc}
\hline Item & Value \\
\hline Acid Value & 0.07 \\
lodine Value & 80.0 \\
Peroxide Value & 0.2 \\
Trans. Fatty Acid(\%) & 44.9 \\
& \\
Fatty acid composition & $\%$ \\
\hline $\mathrm{C}_{16: 0}$ & 12.1 \\
$\mathrm{C}_{18: 0}$ & 7.6 \\
$\mathrm{C}_{18: 1}$ & 74.4 \\
$\mathrm{C}_{18.2}$ & 5.9 \\
\hline
\end{tabular}

containing different DK F-10 concentration $(0.0 \%$, $0.5 \%, 1.0 \%$ ) were analyzed. The SFC of the samples were determined using the following thermal treatment: samples were melted at $70^{\circ} \mathrm{C}$ for 30 minutes before analysis to destroy any crystal history, and then the NMR tubes were filled with about $5 \mathrm{ml}$ samples. Two replicates of each sample were then placed into a thermostated water bath a crystallization temperature $\left(15^{\circ} \mathrm{C}\right)$, and SFC readings were taken at appropriate time intervals. Crystallization rate (Tc) of samples was determined with DSC as reported before (Kawamura, 1979; Nasir, 2001). Melting point of fat measurement followed the AOCS method (AOCS, 1985).

\section{RESULTS AND DISCUSSION}

Figure $1(a, b)$ show the solid fat content (SFC) vs. time of crystallization for samples containing ca. $0.0 \%, 0.5 \%$, and $1.0 \%$ DK F-10 emulsifier at constant temperature of $15^{\circ} \mathrm{C}$. All the three samples showed a rapid increase in SFC during the first two hours (Figure 1a) with slower increase in SFC after that. This behavior is depicted as semi hyperpolic curves in Figure 1a. This indicated that the nuclei growth mechanism follow an aggregate of the nuclei for a high initial number (Herrera, et al., 1999; Ng \&Oh, 1994). Samples containing $0.0 \%$ and $0.5 \%$ DK F-10 showed an insignificant difference of $0.03 \%$ in SFC during the first two hours. While samples containing $1.0 \%$ DK F-10 showed a higher difference of about $1.5 \%$ in SFC as compared to the samples containing $0.5 \%$ DK F-10 during the first two hours. This sharp increase in SFC indicated that there were short induction times of crystallization for all samples with shorter induction time for sample containing 


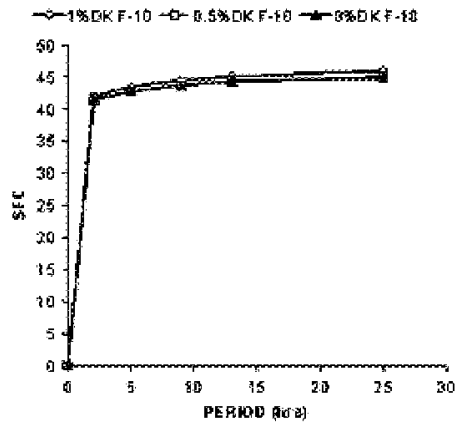

Figure 1a

Efect of dk ester F-10 concentration on SFC* of vegetable ghee at fixed temperature $(15 \mathrm{oc})$ for $25 \mathrm{hrs}$.

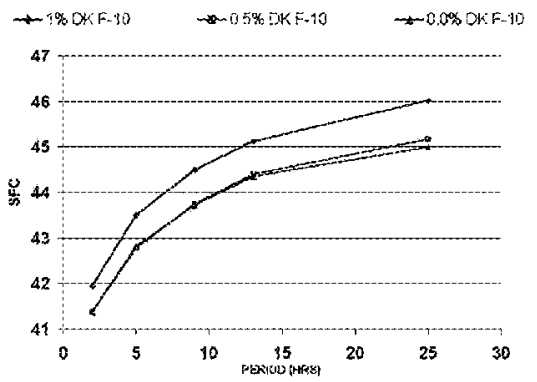

Figure $1 b$

Efect of dk ester F-10 concentration on SFC* of vegetable ghee at fixed temperature $(15 \mathrm{oc})$ for $25 \mathrm{hrs}$.

* The values in the figure are the mean of tetraplicate readings of two samples

1.0\% DK F-10 (Fig-1b). The short induction time for the three samples is in agreement with the short time taken for turbidity developing time in similar temperature range and $T_{c}$ determined by DSC, as reported before (Nasir, 2001).

It seems that the amount of $0.5 \%$ of DK F-10 is not sufficient to be effective to speed up the crystallization rate during the first $13 \mathrm{hr}$. (Garti et al., 1982). Although the difference in melting point of the samples indicated that the emulsifier is incorporated into the crystal lattice and posses the ability to co-crystallize with the fat. Melting points of the three samples are shown in Table II.

The increase of SFC of sample containing $0.5 \%$ DK F-10 more than that of $0.0 \%$ DK F-10 after the 13 $\mathrm{hr}$ may be due to the formation of a crystalline -interaction compound as a result of DK F-10 presence in the fat (deMan et al., 1991).
Table II

Melting point of fat used for producing vegetable ghee with relation to DK F-10 added to it *

\begin{tabular}{ccc}
\hline S. No. & DK F-10 \% & Melting Point ** \\
\hline 1 & $0.0 \%$ & $31.8^{\circ} \mathrm{C}$ \\
2 & $0.5 \%$ & $32.5^{\circ} \mathrm{C}$ \\
3 & $1.0 \%$ & $33.2^{\circ} \mathrm{C}$ \\
\hline
\end{tabular}

${ }^{*}$ Fat lodine Value $=82 .{ }^{* *}$ Melting Point: AOCS Method No. C. C. 1

Sample containing 1.0\% DK F-10 shows higher SFC through out the time of analysis (Fig. 1 a,b) and higher crystallization rates. Turbidity developing time are shorter for sample containing 1.0\% DK F-10 than that of other two samples as reported before (Nasir, 2001). This indicates higher crystallization rate that started from the nucleation stage of crystallization. The amount of SFC for blank samples $(0.0 \%$ DK $\mathrm{F}-10$ ) for a period of $25 \mathrm{hr}$ is equal to SFC of sample containing $1.0 \%$ DK F-10 for a period of $13 \mathrm{hr}$. This means that crystallization rate of sample containing $1.0 \%$ DK F-10 is doubled than that of the crystallization rate of blank sample. This is due to the effective incorporation of DK F-10 into the crystal lattice and the ability to co-crystallize with the fat having similar structure as well as the bulkiness of the hydrophilic group (higher amount of sucrose in SPE) in such a way that it permits fat polymorphic transition and/or higher crystallization rate (Timms, 1984; Lee \& de Man, 1984; Garti et al., 1982). The sufficient amount of emulsifier (1.0\% DK F-10) absorbed in the fat is the precursor to increase the crystallization rate in comparison with the other two samples. Moreover, it is clear from Fig. $1 \mathrm{~b}$ that SFC increases throughout the crystallization time for all three samples, but the increase in the amount of SFC for sample containing 1.0\% DK F-10 is higher than the increase in the amount of SFC for the blank sample, and so the gap between the SFC of the two samples are widened with the passage of crystallization time. In other words, crystallization rate of sample containing 1.0\% DK F-10 continues to be higher than that of other two samples throughout the crystallization period.

But the crystallization rate and polymorphic change in a laboratory environment for a small amount, e.g. an NMR tube or DSC sample capsule, is much more difficult to be related to what happens in the processing line (Timms, 1984). This is what we observed between NMR tube and a $3 \mathrm{~kg}$ of fat in square tin cans both maintained at same temperature. Whereas, in NMR tube, the difference between the sample containing 1.0\% DK F-10 and 
blank sample to reach complete solidification is $12 \mathrm{hr}$ for a period of $25 \mathrm{hr}$. While in case of $3 \mathrm{~kg}$ fat in tin cans of the same samples, the difference is only $5 \mathrm{hr}$ for a period of $18 \mathrm{hr}$ (Nasir, 2001). It means that for NMR tubes the $1.0 \%$ DK F-10 reduces the solidification time to half. On the other hand, it is reduced to about quarter in $3 \mathrm{~kg}$ tin cans. It may be due to the cooling medium i.e. water in NMR and air in case of tin cans, and also due to the size of the solidified fat difference i. e., about $5 \mathrm{~g}$ in NMR tube and $3 \mathrm{~kg}$ in tin cans.

\section{CONCLUSION}

Sucrose polyesters such as DK F-10 are effective in shortening the crystallization time of vegetable ghee when it is added to the fat in comparison with the blank sample. Analysis of SFC vs. time of crystallization of sample having different ratio of emulsifier $(0.0 \%, 0.5 \%$ and $1.0 \%$ DK F-10) with p-NMR indicated that $1.0 \%$ DK F-10 is very effective in increasing crystallization rate and shortening the tempering time required for vanaspati. While $0.5 \%$ DK F-10 did not show significant effect. The results of SFC obtained are in agreement with DSC and with turbidity analysis of our pervious work (Nasir, 2001). But the result obtained by NMR tube under laboratory conditions, although it is similar to that in production of a large scale in the factory, it is not necessary to obtain the same result for the large scale production.

\section{ACKNOWLEDGMENT}

The author expresses his thanks to Engineers $\mathrm{J}$. Karbalaee Sadegh and A. Ahmadi for their assistance during this study.

\section{REFERENCES}

AOCS, (1985). Official and Tentative Methods of the American Oil Chemists Society ( $3^{\text {rd }}$ edn. ). Walker, R.C. (ed.) , AOCS. Champaign.

Breitschuh, B. \& Windhab, E. J. (1996). Direct Measurement of Thermal Fat Crystal Properties for Milk-Fat Fractionation. J. Am. Oil Chem. Soc. 73 , 1603-1610.

DANISCO (1998) Procrystalliser, Technical Memoranda 1523. Danisco Ingredients, Brabrand.

de Man, L.; de Man, J. M. \& Blackman, B. (1991). Physical and Textured Characteristics of some North American Shortenings. J. Am. Oil Chem. Soc. 68, 63-69.
DKS (1998). DK Ester Sucrose Fatty Acid Ester, Daiichi Kogyo Seiyaku Co.. Tokyo.

Gander, K. F. (1976). Margarine Oil, Shortenings, and Vanaspati. J. Am. Oil Chem. Soc. 53, 417-420.

Garti, N.; Wellner, E. \& Sarig, S. (1982). Crystal Structure Modifications of Tristearin by Food Emulsifiers. J. Am. Oil Chem. Soc. 59,181-185.

Herrera, M.L.; Falabella, C.; Melgarejo, M. \& Anon, M. C. (1999). Isothermal Crystallization of Hydrogenated Sunflower Oil II. Growth and Solid Fat Content. J. Am. Oil Chem. Soc. 76, 1-6.

Herrera, M.L. \& Marquez Rocha F. J. (1996). Effects of Sucrose Ester on the Kinetics of Polymorphic Transition in Hydrogenated Sunflower Oil . J. Am. Oil Chem. Soc. 73, 321-326.

Kawamura, K. (1979). The DSC Thermal Analysis of Crystallization Behavior in Plam Oil. J. Am. Oil Chem. Soc. 56, 753-758.

Lee, S. \& de Man, J. M. (1984). Effect of Surfactants on the Polymorphic Behavior of Hydrogenated Canola Oil. Polymorphic Behavior of Hydrogenated
Fette. Seifen. Anstrichmittel. 86, 460-465.

Nakamura, S. (1997). Using sucrose esters as food emulsifiers, INFORM. 8, 866-874.

Nasir , M. I. (2001). Effect of Sucrose Polyesters and Sucrose Polyester-Lecithins on Crystallization Rate of Vegetable Ghee in "Crystallization and Solidification Properties of lipids". Widlak, N. ; Hastel, R. \& Narine, S. (eds), Chap. 7, p.p. 87-95 AOCS Press, Champaign.

Ng,W.L. \& Oh,C.H. (1994). A Kinetic Study on Isotherma Crystallization of Palm Oil by Solid Fat Content Measurements. J. Am. Oil Chem. Soc. 71,1135-1139.

Nor Aini, I. (1993). The Use of Palm Oil Productions in Shortenings and Vanaspati in Selected Readings on Palm Oil and its Uses, P. P. 68-80, Palm Oil Research Institute of Malaysia, Kuala Lampur.

O'Brien, R. D. (1996). Shortening :Types and Formulations in Baileys Industrial Oil \& Fat Products, Hui, Y. H. (ed.), $5^{\text {th }}$ ed. , Vol. 3 , P. P.-- 161-192, John Wiley \& Sons, New York.

Ray, S. \& Bhattacharaya, D. K. (1996). Comparative Nutritional Quality of Palmstearin-Liquid Oil Blends and Hydrogenated Fat (Vanaspati). J. Am. Oil Chem. and Hydrogenate

Timms, R. E. ( 1984 ). Phase Behaviour of Fat and their Mixtures. Prog. Lipid Res. 23, 1-38.

van Duynhoven, J.; Goudappel, G.--J.; Gribnau, M. C. M. \& Shukla V. K. S. (1999). Solid fat content determination by NMR. INFORM. 10, 479-484.

Yuki, A. ; Matsuda, K. \& Nishimura, A. (1990). Effect of Sucrose Polyesters on Crystallization Behaviour of Vegetable Shortening and Margarine Fat. J. Jpn. Oil Chem. Soc. 39, 236-244.

Recibido:Enero 2002 Aceptado: Febrero 2003 